Int. J. Dev. Biol. 60: 95-102 (2016)

doi: $10.1387 / \mathrm{ijdb} .160010 \mathrm{hn}$

\title{
The effect of amniotic membrane stem cells as donor nucleus on gene expression in reconstructed bovine oocytes
}

\author{
HASSAN NAZARI ${ }^{1,3}$, ABOLFAZL SHIRAZI ${ }^{*, 2,3,4}$, NASER SHAMS-ESFANDABADI ${ }^{5}$, AZITA AFZALI $^{6}$ \\ and EBRAHIM AHMADI ${ }^{3}$

\begin{abstract}
${ }^{1}$ Faculty of Veterinary Medicine, Shahrekord University, Shahrekord-Iran, ${ }^{2}$ Reproductive Biotechnology Research Center, Shahrekord-Iran, ${ }^{4}$ Department of Clinical Sciences, Faculty of Veterinary Medicine, Shahrekord University, Shahrekord-Iran, ${ }^{5}$ Department of Clinical Sciences, Faculty of Veterinary Medicine, Shahrekord University, Shahrekord-Iran, ${ }^{6}$ Faculty of Basic Sciences, Shahrekord University, Shahrekord-Iran.
\end{abstract} \\ Avicenna Research Institute, ACECR, Tehran-Iran, ${ }^{3}$ Research Institute of Animal Embryo Technology, Shahrekord University,
}

\begin{abstract}
Nuclear reprogramming of a differentiated cell in somatic cell nuclear transfer (SCNT) is a major concern in cloning procedures. Indeed, the nucleus of the donor cell often fails to express the genes which are a prerequisite for normal early embryo development. This study was aimed to evaluate the developmental competence and the expression pattern of some reprogramming related genes in bovine cloned embryos reconstructed with amniotic membrane stem cells (AMSCs) in comparison with those reconstructed with mesenchymal stem cells (MSCs) and adult fibroblasts (AF) as well as with in vitro fertilized (IVF) oocytes. In vitro matured abattoir-derived oocytes were considered as recipients and a hand-made cloning technique was employed for oocyte enucleation and nuclear transfer (NT) procedures. The expression pattern of genes involved in self-renewal and pluripotency (POU5F1, SOX2, NANOG), imprinting (IGF2, IGF2R), DNA methylation (DNMT1, $D N M T 3 A)$, histone deacetylation (HDAC2), and apoptosis (BAX, BCL2) were evaluated in NT and IVF derived embryos. Despite the insignificant difference in cleavage rate between reconstructed and IVF oocytes, the blastocyst rate in the IVF group was higher than that of other groups. Among reconstructed oocytes, a higher blastocysts rate was observed in MSC-NT and AMSCs-NT derived embryos that were significantly higher than AF-NT derived ones. There were more similarities in the expression pattern of pluripotency and epigenetic modification genes between MSC-NT and IVF derived blastocysts compared with other groups. In conclusion, considering developmental competence, AMSCs, as alternative donors in SCNT procedure, like MSCs, were prone to have more advantage compared with $\mathrm{AF}$.
\end{abstract}

KEY WORDS: nuclear transfer, reprogramming, bovine, imprinting, embryo

\section{Introduction}

Somatic cell nuclear transfer (SCNT) is an incompetent process in embryo production. There are numerous factors/causes affecting the success rate of SCNT procedure. Donor cells differentiation status is one of those factors that can influence the development of NT-derived embryos. It is thought that in nuclear transfer (NT), the nucleolus of undifferentiated stem cells may be more easily reprogrammed as the genome of reconstructed oocytes (Kumar et al., 2007). Among many types of stem cells, mesenchymal stem cells (MSCs) are on the leading edge as they are easy to expand in culture while maintaining their stemness properties. Bovine MSC as a first type of adult stem cells has been used in SCNT procedure with an appropriate nuclear reprogramming after NT and successful live birth. (Kato et al., 2004). Cloned embryos derived from bovine and porcine undifferentiated MSCs have consistently resulted in high preimplantation development compared to adult fibroblasts (Colleoni et al., 2005). Amniotic membrane stem cells (AMSCs), with their following biological characteristics such as low immu-

\footnotetext{
Abbreviations used in this paper: $\mathrm{AF}$, adult fibroblast; AMSC, amniotic membrane stem cell; IVC, in vitro culture; IVF, in vitro fertilization; MSC, mesenchymal stem cell; SCNT, somatic cell nuclear transfer.
}

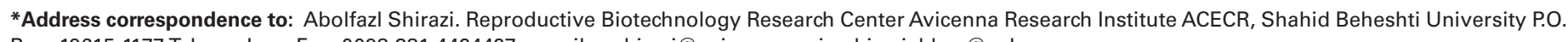
Box: 19615-1177,Tehran, Iran. Fax: 0098-381-4424427. e-mail: a.shirazi@avicenna.ac.ir; shiraziabbas@yahoo.com

Accepted: 6 April 2016.

ISSN: Online 1696-3547, Print 0214-6282 
nogenicity, low tumorigenicity upon transplantation, widespread availability, and lack of ethical problems associated with their use have attracted the attention of researchers (Toda et al., 2007). Application of AMSCs in SCNT is limited to few studies on some species such as porcine (Zheng et al., 2009). In these studies the characteristics of SCNT embryos in both types of nuclear donors, MSCs and AMSCs, have indicated their adequate reprogramming potential. However, it has already remained to be elucidated which of them is more appropriate in NT and how extent their differentiation status is crucial in cloning efficiency.

As known, the low efficiency of post implantation development of embryos following NT of differentiated cells, at least in part, is due to faulty nuclear reprogramming, leading to defects in early embryo gene expression (Rodriguez-Osorio et al., 2012, Samiec and Skrzyszowska, 2005). During normal development, early embryos undergo a well-orchestrated series of DNA methylation and histone modification that are believed to play an important role in establishing a condition in which the chromatin will be permissive to early embryonic gene expression. In contrast, NT-derived embryos typically show abnormal patterns of DNA methylation and histone modifications and the consequent abnormal expression of genes in early embryo (Bortvin et al., 2003, Jaenisch et al., 2004). Studies on pre-implantation development of SCNT embryos have shown significant deficiencies in many parts of nuclear events, including transcription and translation, epigenetic modifications such as methylation of DNA, acetylation of histones and chromatin configuration as well as genetic imprinting (Kumar et al., 2007). In support of these observations, mammalian NT-derived embryos displayed so many abnormalities caused by aberrant expression of genes involved in early development and epigenetic reprogramming (Niemann et al., 2008). However, the amount of data collected associated with gene expression in preimplantation cloned embryos, reconstructed with AMSCs, is limited to a few genes. Accordingly, in the present study, we aimed to evaluate and compare the developmental competence as well as the expression of panel of developmentally important genes involved in early embryo development in resulting blastocysts derived from bovine oocytes reconstructed with amniotic membrane stem cells (AMSCs), mesenchymal stem cells (MSCs), and adult fibroblasts (AF).

\section{Results}

The stemness status of AMSCs and MSCs was confirmed after their differentiation to adipoctyes and osteocytes followed by Oil red and Alizarin red staining, respectively. Their stemness status was also confirmed by the presence of OCT4 protein by immunocytochemistry method.

As shown (Table 1), after $24 \mathrm{~h}$ of culture there was a significant difference in cleavage rate between groups $(p<0.05)$; so that among NT embryos those derived from AMSCs and AF had the highest and lowest cleavage rate, respectively. The difference among groups, however, was lost in the next day.

Despite the lower developmental of NT embryos compared to IVF ones $(p<0.05)$, the use of stem cells (MSCs or AMSCs) improved developmental competence of reconstructed embryos compared to fibroblast $(p<0.05)$. However, there was no significant difference between AMSCs-NT and MSCs-NT embryos. As shown (Table 1), the lowest blastocyst rate was also observed in the AF-NT group compared to other groups.
TABLE 1

\section{DEVELOPMENTAL RATE IN BOVINE IVF AND NT EMBRYOS}

\begin{tabular}{|c|c|c|c|c|c|}
\hline \multirow[b]{2}{*}{ Groups } & \multirow[b]{2}{*}{ Oocyte No. } & \multicolumn{2}{|c|}{ Cleavage rate (\%) } & \multicolumn{2}{|c|}{ Blastocyst rate (\%) } \\
\hline & & Day 1 & Day 2 & Day 7 & Day 8 \\
\hline IVF & 438 & NA & $74.34 \pm 1.36$ & $23.6 \pm 0.71^{a}$ & $26.72 \pm 0.64^{a}$ \\
\hline AF-NT & 363 & $42.51 \pm 2.79^{a}$ & $73.7 \pm 1.19$ & $9.27 \pm 0.89^{b}$ & $12.65 \pm 0.64^{b}$ \\
\hline MSC-NT & 370 & $48.72 \pm 1.85^{\mathrm{b}}$ & $79.79 \pm 2.36$ & $16.48 \pm 2.09^{\circ}$ & $19.23 \pm 1.65^{c}$ \\
\hline AMSC-NT & 328 & $56.40 \pm 1.26^{c}$ & $80 \pm 3.56$ & $16.1 \pm 2.99^{c}$ & $17.95 \pm 3.01^{\mathrm{DC}}$ \\
\hline
\end{tabular}

$A, b, c$ Different superscripts in the same column denote a significant difference $(p<0.05)$. Data represent $n=6$ replicates.

The relative abundance (RA) of transcripts at the blastocyst stage in cloned and IVF embryos has been shown in Fig. 1A-J.

As shown, the expression of POU5F1 in IVF derived blastocysts was higher than NT derived ones. Though, the difference was in significant between IVF and MSC-NT derived embryos.

The highest and lowest expression of NANOG were observed in AMSC-NT and IVF derived embryos, respectively $(\mathrm{p}<0.05)$. No significant difference was observed between AF-NT and MSCs-NT derived embryos.

Similarly, the highest and lowest expression of SOX2 were observed in AMSC-NT and IVF derived embryos, respectively $(p<0.05)$. However, there was no significant difference between NT derived blastocysts.

The relative abundance of DNMT1 transcript was significantly $(p<0.05)$ higher in AF-NT and AMSC-NT than IVF and MSC-NT embryos. There was no significant difference between AF and AMSC-NT and between IVF and MSC-NT embryos.

The RA of DNMT3A was similarly higher in AF-NT and AMSCsNT embryos compared to IVF and MSCs-NT groups. However, the difference between MSCs-NT and AMSCs-NT embryos was insignificant.

HDAC2 exhibited high level of expression in IVF embryos compared to NT derived counterparts, $(p<0.05)$ and no differences were found between NT groups.

The RA of IGF2 transcript was similar between groups and no significant differences were observed. The expression of IGF2R in AF-NT embryos was significantly higher than other groups.

No significant difference in $B A X$ expression was observed between groups, while the expression of BCL2 in AF-NT derived blastocysts was significantly lower than other groups.

\section{Discussion}

Somatic cell nuclear transfer (SCNT) efficiency in livestock is relatively low. In cattle only $1.7 \%$ of reconstructed oocytes and $11.5 \%$ of transferred NT embryos develop to term, and some of them exhibiting abnormalities at birth (Keefer, 2015). The main obstacle in SCNT procedure is thought to be in appropriate reprogramming of the donor nucleus (Niemann et al., 2008). Among different component of SCNT, type of donor cell and its differentiation status may influence the quality of resulting embryo and its subsequent postimplantation development. While, some studies have shown that there is no difference between fully differentiated and less differentiated donor cells in SCNT procedure, there is evidence indicating a less differentiated donor cell can increase SCNT efficiencies compared with terminally differentiated cell types. 
In the present study application of fibroblast as donor cell in NT procedure using HMC method resulted in $12.65 \%$ blastocyst. Despite lack of study using this method in production of cattle NT embryos, the application of this method using AF-NT reconstructed oocytes resulted in $8.8 \%$ to $13.2 \%$ and $19.5 \%$ blastocyst rate in sheep (Hosseini et al., 2013a, Hosseini et al., 2013b) and goat (Hosseini et al., 2015), respectively. Regarding the use of stem cells as donor cells, the porcine MSC-NT reconstructed oocytes had a higher developmental rate compared to the fetal fibroblastNT derived counterparts (Jin et al., 2007, Samiec et al., 2015). The higher appropriate remodeling of stem cell-NT derived embryos has proved in different species (Bosch et al., 2006, Faast et al., 2006, Kumar et al., 2007, Kumar et al., 2012, Lee et al., 2006, Rideout et al., 2000). Some reports, however, have rejected transcendence of stem cells over somatic cells in normal reprogramming of NT derived embryos (Berg et al., 2007, Li et al., 2013, Sung et al., 2006). In the first report on the use of bovine MSCs for NT, no priority in developmental potential was observed in stem cell derived embryos compared to non-stem cell derived counterparts (Kato et al., 2004). On the contrary, cloned embryos derived from bovine and porcine undifferentiated MSCs and their derivatives gave rise to the higher preimplantation development compared to adult fibroblasts (Colleoni et al., 2005).

In our study condition, despite the lower developmental rate of NT derived embryos compared to the IVF derived ones, the use of stem cells (MSCs or AMSCs) as donor cells could improve developmental competence of reconstructed oocytes compared to those reconstructed with fibroblasts.

To the best of our knowledge, this study is the first report on the use of AMSCs as a donor in bovine NT that compare mRNA expression of a panel of development-related genes among cloned blastocysts derived from different donor cells. However, further data on post implantation development are needed to shed more light on the effect of the stem cell nature of the donor nucleus in SCNT. In the only report on the use of amnion derived stem cells for NT, the resulting porcine blastocyst and pregnancy rates were higher than those reconstructed with fully differentiated somatic cells (Zheng et al., 2009). Aberrant gene expression is one of the suggested causes of the low success rates of development in NT embryos of mammals.

During normal development, the early embryo undergoes a series of coordinated epigenetic modifications (e.g. DNA methylation and histone modifications), which plays an important role in creating an appropriate chromatin status for gene expression in early embryo. Considering the occurrence of some abnormalities in gene expression of SCNT embryos, in the present study the expression of some genes involved in reprogramming, epigenetic modifications, apoptosis, and imprinting were assessed as indicators of quality of NT produced embryos.

POU5F1 or OCT4 (octamer-binding transcription factor 4) as a marker for undifferentiated cells, critically involved in self-renewal and pluripotency of stem cells across mammalian
Apoptosis

$$
\text { I }
$$

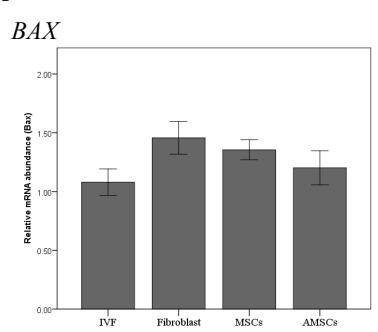

J

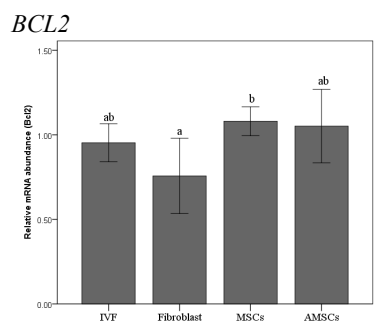

Fig. 1. Relative abundance of POU5F1 (A), NANOG (B), SOX2 (C) DNMT1 (D), DNMT3A (E), HDAC2 (F), IFG2 (G), IGF2R (H), BAX (I) and $B C L 2(\mathrm{~J})$ transcripts in bovine blastocyst derived from IVF and NT (AF, MSCs, and AMSCs). mRNA from pools of 4 embryos at the blastocyst stage were reverse transcribed, and subjected to real-time quantitative $P C R$. All reactions were normalized for histone $\mathrm{H} 2 \mathrm{~A}$ mRNA expression. Values with superscripts "abc" refers to significant $(p<0.05)$ differences in relative transcript abundance between groups. 
species and is presumed to be a critical factor controlling murine, porcine, and bovine preimplantation embryonic development. It has been shown that the POU5F1 expression in cloned embryos at blastocyst stage is lower than in vivo and IVF derived blastocysts. In porcine, POU5F1 expression in MSCs-NT and AF-NT derived blastocysts was significantly decreased compared with IVF and in vivo derived counterparts (Kumar et al., 2007); Whereas, the low expression of POU5F1 is associated with low developmental competence of embryos, a decreased POU5F1 expression in NT derived embryos might be the reason for their lower blastocyst rates compared to the IVF derived embryos. Since the methylation status of gene promoter is associated with its expression, the higher expression of POU5F1 in IVF and MSC-NT derived blastocysts might be related to the lower expression of DNMT1\&2 in these groups. It has been shown that porcine bone marrow MSCs with high level of POU5F1 expression are more potent as NT donor cells and that POU5F1 transfection of MSCs has improved the developmental competence of NT derived embryos (Lee et al., 2014). It has also been shown that POU5F1 expression in bovine fibroblasts positively correlates with blastocysts formation and total cell number of NT derived embryos (Rodriguez-Alvarez et al., 2013). Therefore, the higher blastocysts rates in IVF and MSCsNT derived embryos might be related, at least partly, to the higher expression of POU5F1 in these groups.

SOX2 as an another gene involved in pluripotency, is a transcription factor that is essential for maintaining pluripotency and self-renewal of stem cells and also plays a key role in many stages of mammalian development. In the present study, despite no significant difference in SOX2 expression between IVF and AF and MSC-NT embryos, the expression in AMSCs-NT derived blastocyst was higher than IVF embryos. It seems the expression of this gene is not associated with survival rate (Kumar et al., 2012) so that the lower SOX2 expression in IVF group has no adverse effect on embryo development in this group. This finding was consistent with previous report indicating the low expression of SOX2 in porcine IVF, parthenogenetic, and NT embryos reconstructed with MSCs or fetal fibroblast (Kumar et al., 2012). However, the higher expression of this gene in post-hatching stages (Kumar et al., 2012) may indicate it's more important role during or after implantation.

NANOG is a homeobox-containing transcription factor with an essential function in maintaining the pluripotent status in inner cell mass as well as ESCs (Mitsui et al., 2003). It has been shown that overexpression of NANOG in donor cells had no effect on blastocyst rate in reconstructed embryos (Zhang et al., 2011). In our present study, similarly, the higher expression of NANOG in cloned AMSC-NT embryos could not improve the embryo development. There is evidence indicating the culture system may affect the NANOG expression. For instance its expression might be affected by differences in IVF and NT culture systems (group culture in IVF and WOW in NT system). This hypothesis that how extent the concentration of metabolites such as ammonium may be influenced by the culture system and how it may influence the expression of NANOG need to be further investigated.

As shown in contrast to SOX2 and NANOG, the expression of POU5F1 in IVF derived blastocyst was higher than SCNT derived counterparts, except for MSC-NT embryos and this might be the reason for the higher blastocyst rate in MSC-NT group compared to other SCNT groups.

Among DNA-methyltransferases, DNMT1 as abundant DNA methyltransferase is responsible for copying methylation patterns following DNA synthesis, whereas DNMT3A\&B are involved in de novo methylation (Dean et al., 1998). Previous studies have shown a correlation between incomplete DNA methylation and the lack of NT success in mammals (Bortvin et al., 2003, Dean et al., 2001). DNMT1 and DNMT3A mRNA were continuously identified in in vitro produced bovine embryos from 2-cell to the blastocyst stages (Golding and Westhusin, 2003). The relative abundance of the DNMT1 transcript, however, was significantly lower in in vivo derived bovine embryos compared with in vitro counterparts (Wrenzycki et al., 2001a). In our study, the lower expression of both DNMT1 and DNMT3Ain IVF and MSCs-NT derived blastocysts compared to AF-NT and AMSC-NT counterparts may be related to the higher developmental competence of the blastocysts in the former groups due to the higher chance of expression of developmentally important genes. In some previous reports there are evidences indicating similarities in DNMT1 expression between in vivo and in vitro embryos and that the amount of DNMT3A transcripts in bovine IVF embryos is higher than NT embryos (Rodriguez-Osorio et al., 2009). In porcine, SCNT derived blastocyst using terminally differentiated somatic cells had a higher DNMT1 expression compared to the either IVF or stem cell-NT derived blastocysts as well as in vivo produced embryos (Zhu et al., 2004). In agreement with our study, DNMT3A expression in porcine IVF embryos was not significantly different with MSC-NT counterparts (Lee et al., 2014).

From above is not easy to draw a final conclusion about the consequences of lower expression of DNMTs in IVF and MSCs-NT derived blastocysts on further post hatching embryo development. One possibility for the lower DNMT1\&3A in MSCs-NT derived blastocysts compared to AF and AMSCs-NT derived counterparts might be related to the difference in methylation status of donor cells in these groups. It seems the methylation status of donor cells tend to be remained in SCNT embryos even after several cell divisions in embryos. In support of this, in blastocysts derived from treated MSCs in which the DNMT1 expression was downregulated, DNMT1 expression was lower than cloned blastocysts derived from untreated MSCs (Kim et al., 2014). Therefore, in cattle cloned embryos there is a tendency to preserve the DNA methylation patterns inherited from their donor cells (Bourc'his et al., 2001).

Histone acetylation is regulated by two classes of enzymes, the histone acetyltransferases (HAT's) and histonedeacetylases (HDAC's). Histone Acetylation facilitates chromatin decondensation so that makes the DNA more accessible to transcriptional factors, while HDAC's through histones deacetylation counteract this effect (Wolffe and Pruss, 1996). In the present study, in contrast to DNMTs, HDAC2 exhibited a high level of expression in IVF embryos compared to NT counterparts and no differences were found between NT groups. In agreement to this finding, in pig and cattle the HDAC2 expression in IVF embryos was higher than cloned embryos (Kumar et al., 2007). The abnormal reprogramming due to aberrant histone modifications following SCNT has been documented by other studies (Enright et al., 2005, Santos et al., 2003).

The IGF2and IGF2Rgenes asmaternally and paternally inherited genes, respectively, are among the best studied imprinted genes involved in fetal growth regulation, and are essential for normal development (Latham et al., 1994). IGF2 is a classic imprinted gene as it appears to be biallelically transcribed up to the morula stage, but in the blastocyst stage the maternal IGF2 allele is silenced. Aberrant expression of imprinted genes may be responsible for devi- 
ated growth characteristics seen in fetuses and offspring originated from embryos produced in in vitrosystems, including SCNT derived embryos (Niemann et al., 2002). In our study, the IGF2 expression was similar in all studied groups, while the expression of IGF2R in AF-NT blastocysts was greater than other groups. In porcine, despite no difference in IGF2Rexpression in IVF, parthenogenetic, and SCNT derived blastocysts, the expression in in vivo derived blastocysts was higher than in vitro derived counterparts (McElroy et al., 2008). In one report no significant difference was observed in IGF2R expression between bovine IVF and cloned embryos (Niemann et al., 2002). There are also evidences indicating the higher IGF2R expression, in in vitro-produced bovine and porcine embryos (Bertolini et al., 2002, Kumar et al., 2007), with no differences in expression levels between IVF and SCNT blastocysts (Han et al., 2003, Kumar et al., 2007, Wrenzycki et al., 2001b). It was demonstrated that any in vitro manipulation of the embryo might induce epigenetic modifications in various developmentally important genes including imprinted genes (Feil, 2001, Niemann et al., 2002). There are also evidences indicating the effect of culture systems on expression pattern of imprinted genes. For instance, extended culture of murine embryos in deficient medium (e.g., Whittens' medium) led to biallelic expression of the $\mathrm{H} 19$ and that the vicinity of embryos in group culture increased ammonium concentration which in turn could induce aberrant expression of the imprinted genes in blastocysts (Doherty et al., 2000).

Another group of genes which play an important role during embryo development were pro-apoptotic $(B A X)$ and Anti-apoptotic (BCL2) genes (Metcalfe et al., 2004). In our study the BAX expression in IVF derived blastocysts was similar to NT embryos, while the transcript abundance of $B C L 2$ in AF-NT blastocysts was significantly lower than MSC-NT embryos whereas no differences were detected between IVF, MSC-NT, and AMSC-NT embryos.

In porcine, the $B A X$ expression was significantly higher in FFNT embryos than in MSC-NT and IVF derived embryos (Kumar et al., 2007). There are also evidences indicating the relationship between total cell number, embryo fragmentation, number of apoptotic cells, and developmental potential of embryos with expression of cell death regulatory genes, $B A X$ and $B C L 2$ (Jin et al., 2007). The elevation and reduction in expression of $B A X$ and $B C L 2$, respectively, is more evident in cloned embryos than their IVF counterparts (Kumar et al., 2007). Considering the lack of difference in $B A X$ expression between groups, the lower development competence in AF-NT derived embryos might be related to the lower expression of $B C L 2$ in this group.

As discussed above, in our study condition the expression of the majority of genes in IVF and NT derived blastocysts were different. Indeed, the most similarities in gene expression between NT and IVF groups were seen in MSC-NT blastocysts, especially the expression of POU5F1, DNMT1, and DNMT3A. In the other hand, the higher developmental competence of oocytes reconstructed with MSCs compared to other NT oocytes, might be related, at least partly, to the similarities in genes expression between MSCs-NT and IVF groups. Additionally, application of AMSCs as donor cell in SCNT procedure was more appropriate compared with adult fibroblast.

\section{Materials and Methods}

\section{Chemicals and media}

Except where otherwise indicated, all chemicals were obtained from the Sigma (St. Louis, MO, USA).

\section{Experimental design}

The abattoir derived oocytes after IVM were subjected either to IVF/ IVC, as control, or enucleated as recipient cytoplasts for 3 different donor cells. For NT, all donor cells were used in the third passage. The IVF and chemically activated reconstructed oocytes were separately cultured for 8 to 9 days. The cleavage and blastocyst rates were recorded on days 3 and 7 to 8 after IVC, respectively. The resulting blastocysts were then subjected to RNA extraction and quantification using RT-PCR method.

\section{Donor cell preparation}

\section{Adult fibroblast cells}

Preparation of AF was performed according to Heidari et al., method (2010). Briefly, ear skin biopsy samples of a 12-month-old bull was washed in $\mathrm{Ca}^{2+}$ and $\mathrm{Mg}^{2+}$ free PBS and finely minced with a sterile scalpel blade. The explants transferred to $60 \times 10 \mathrm{~mm}$ Falcon TM plastic Petri dishes (Falcon 3004; Becton Dickinson) and cultured in DMEM containing 40\% fetal calf serum (FCS; Gibco 10270) supplemented with100IU/ml penicillin and $100 \mathrm{ug} / \mathrm{ml}$ streptomycin, $2 \mathrm{mM} \mathrm{L-glutamine} \mathrm{(Gibco,} \mathrm{Grand} \mathrm{Island,} \mathrm{NY),}$ and $25 \mathrm{mM} \mathrm{NaHCO} 3$ at $38.5^{\circ} \mathrm{C}$ and $5 \% \mathrm{CO}$. After $48 \mathrm{~h}$, the culture medium was replaced by DMEM medium supplemented with $10 \%$ FCS. Fibroblast cells began to outgrow from the explants by the third day in culture and the explants were removed from the Petri dishes on day 6. After explants removal, the cells were harvested at $60 \%$ confluency using trypsin/EDTA in PBS, counted and seeded at $5 \times 10^{5}$ cells into $25 \mathrm{~cm}^{2}$ tissue culture flasks. The first passage was carried out at $90 \%$ confluency and $1 \times 10^{6} \mathrm{cells} /$ cryovial was considered for cryopreservation in DMEM containing $40 \%$ FCS and $10 \%$ DMSO.

\section{Amniotic membrane stem cells}

The AMSCs were obtained from amniotic membrane at75-90 days of pregnancy. The amniotic membrane was separated under a stereomicroscope into epithelial and connective tissues. AMSCs were obtained from epithelial tissue following 30 minutes of enzymatic digestion in DMEM containing collagenase type IV $(1 \mathrm{mg} / \mathrm{ml})$, hyaluronidase $(0.5 \mathrm{mg} / \mathrm{ml})$, trypsin $(1 \mathrm{mg} / \mathrm{ml} /)$, and DNase $(50 \mathrm{IU} / \mathrm{ml})$. After 10 minutes centrifugation at $500 \times \mathrm{g}$, isolated cells were resuspended in DMEM containing $20 \% \mathrm{FCS}$ and $5 \mathrm{ng} /$ $\mathrm{ml}$ fibroblast growth factor (FGF) and were cultured at $38.5^{\circ} \mathrm{C}$ in $5 \% \mathrm{CO} 2$. After 7 days of culture, nonadherent cells were removed and the medium was refreshed every 2 days up to $80-90 \%$ confluency. At desired confluency, the cells were isolated by incubation in $0.25 \%$ Trypsin/EDTA for 10 minutes and were then plated at $2 \times 10^{4} \mathrm{cells} / \mathrm{ml}$.

The stemness status of AMSCs was confirmed by Oct-4 expression, using specific primary antibody, monoclonal anti-Oct-4 (Abcam, ab18976), and FITC-conjugated secondary antibody. The cell nuclei were also stained with $5 \mu \mathrm{g} / \mathrm{mL} \mathrm{H} 33342$ and finally, the stained cells were analyzed under fluorescent microscope. The stemness status of AMSCs at third passage was also confirmed by their osteogenic and adipogenic differentiation. Osteogenic medium was comprised of $10 \%$ FCS, $150 \mu \mathrm{g} / \mathrm{ml} \beta$-glycerophosphate, $50 \mu \mathrm{g} /$ $\mathrm{ml}$ ascorbic acid, and $10^{-8} \mathrm{M}$ dexamethasone, and adipogenic differentiation medium was consisted of $2 \%$ FCS and $100 \mathrm{IU} / \mathrm{ml}$ ITS. Osteogenic and adipogenic differentiation were assessed by colorimetric visualization of calcium sediment (Alizarin Red S stain) and intracellular accumulated lipid-rich vacuoles (Oil red) in culture plates, respectively.

\section{Mesenchymal stem cells}

The adipose tissue from lumbar paravertebral regions after washing 3 times in PBS was minced into small pieces and subjected to enzymatic digestion using collagenase type IV $(1 \mathrm{mg} / \mathrm{ml})$, hyaluronidase $(0.5 \mathrm{mg} / \mathrm{ml})$, trypsin $(1 \mathrm{mg} / \mathrm{ml})$, and DNase $(50 \mathrm{lU} / \mathrm{ml})$ at $37^{\circ} \mathrm{C}$ for $30 \mathrm{~min}$. The digested specimen was centrifuged at $500 \mathrm{~g}$ for $5 \mathrm{~min}$ and the cellular pellet after washing, three times, were cultured in DMEM medium at $38.5^{\circ} \mathrm{C}$ and $5 \%$ CO2. After 3 days of culture, nonadherent cells were removed and the medium was refreshed every 3 days until the culture became confluent. Assessment of stemness status of MSCs was similar to AMSCs. 


\section{Oocyte in vitro maturation}

In vitro maturation (IVM) of bovine oocytes was carried out as described previously (Shirazi et al., 2009). In brief, all visible follicles with a diameter of 2-9 mm of abattoir-derived ovaries were aspirated using a $10 \mathrm{ml}$ syringe fitted with an 18 gauge needle. The aspiration medium was preincubated HEPES-buffered tissue culture medium-199 (HTCM-199) supplemented with penicillin/streptomycin and $50 \mathrm{IU} / \mathrm{ml}$ heparin. The cumulus-oocyte complexes (COCs) with at least three layers of cumulus cells engulfing oocyte with evenly granulated cytoplasm were selected for the experiments. Ten to 15 selected COCs were in vitro matured in $50 \mu$ l of TCM 199 supplemented with $10 \% \mathrm{FCS}$ and $0.1 \mathrm{IU} / \mathrm{ml} \mathrm{FSH}$ in $5 \% \mathrm{CO} 2$ atmosphere at $39^{\circ} \mathrm{C}$.

\section{Oocyte enucleation}

After 20-22h IVM, oocytes were denuded by vortexing in HTCM-199 supplemented with $10 \% \mathrm{FCS}$ and $0.3 \mathrm{mg} / \mathrm{ml}$ hyaluronidase. The oocytes with visible degenerative changes or physical damage were discarded from the experiments. Zona pellucida was removed, by incubation of oocytes for $2-3 \mathrm{~min}$ in medium containing $0.25 \%$ pronase.

For induction of metaphase plate protrusion, bovine zona-free oocytes were incubated in enucleation medium containing $0.5 \mathrm{\mu g} / \mathrm{ml}$ demecolcine for $90 \mathrm{~min}$. The oocyte enucleation was performed by removing the protruded cytoplasm under a stereomicroscope using finely drawn hand-made pipettes as described by Hosseini et al., (Hosseini et al., 2013b). In brief, zona-free oocytes with cytoplasmic protrusion were placed in groups of ten in enucleation medium under mineral oil. First the oocyte was moved by the tip of the pipette in such a way that the cytoplasmic protrusion was placed adjacent to the enucleation pipette. The pipette tip was then attached to the cytoplasmic protrusion so that the protruded cytoplasm is drawn into the needle by gentle mouth suction. The enucleation was then simply accomplished by removing the pipette tip from the enucleation droplet to the mineral oil. The enucleation was then checked after incubation of remaining cytoplasm in $5 \mu \mathrm{g} / \mathrm{ml} \mathrm{H33342}$ for 5 min under an epifluorescent microscope.

\section{Cell attachment}

The serum starved donor cells at the third passage were considered for NT. Fifty to one hundred donor cells were added to a drop of HTCM-199 containing $10 \mathrm{mg} / \mathrm{ml}$ Phytohemagglutinin (PHA-P). The cytoplasts (enucleated oocytes) were individually rolled over a single donor cell to produce donor cell-recipient cytoplast couplets. The couplets were then transferred into wash drops (HTCM-199 supplemented with $10 \% \mathrm{FCS}, 30 \mu \mathrm{g} / \mathrm{ml}$ PVA, and $50 \mu \mathrm{g} / \mathrm{ml} \mathrm{BSA}$ ) before being incubated in fusion buffer (0.3M mannitol, $100 \mu \mathrm{M}$ MgSO4, $50 \mu \mathrm{M} \mathrm{CaCl} 2,500 \mu \mathrm{M}$ HEPES, $0.05 \% \mathrm{BSA}$ ) for $1 \mathrm{~min}$. The 10-15 couplets were then placed in a fusion chamber (electrodes $0.5 \mathrm{~mm}$ apart) and after being manually aligned were received $A C$ pulse ( $7 \mathrm{~V}$ for 2sec). Fusion was induced by applying two DC electrical pulses (1.5KV/ $\mathrm{cm}$ for $30 \mu \mathrm{sec}$; BLS). After electrofusion, the couplets were incubated in HTCM-199 supplemented with $20 \%$ FCS for 30 min and then processed for activation and embryo culture.

\section{Artificial activation and culture}

Thirty minutes after fusion, reconstructed oocytes were transferred to HSOF medium containing $5 \mu \mathrm{M}$ ionomycin for $4 \mathrm{~min}$. They were then washed in HSOF containing $30 \mathrm{mg} / \mathrm{mlBSA}$ to inactivate ionomycin and then incubated in 2mM 6-dimethylaminopurine prepared in SOFaaBSA (SOF supplemented with $2 \mathrm{mM}$ glutamine, essential and non-essential amino acids and $8 \mathrm{mg} / \mathrm{ml}$ $\mathrm{BSA}$ ) medium for $4 \mathrm{~h}$. Following activation, five to six reconstructed embryos were washed and separately cultured based on well of the well (Vajta et al., 2000) culture system in $20 \mu \mathrm{l}$ droplets of SOFaaBSAmedium under oil at $39^{\circ} \mathrm{C}$ in an atmosphere of $5 \% \mathrm{CO} 2,7 \% \mathrm{O} 2$, and $88 \% \mathrm{~N} 2$. On Day 3 , the culture medium was refreshed with the medium containing $5 \%$ charcoal-striped FCS. The cleavage rate was recorded 24 to $48 \mathrm{~h}$ post activation and development to the blastocyst stage was assessed on days 7 and 8 . Day 7 blastocysts were considered for subsequent molecular evaluation.
TABLE 2

\section{SEQUENCE AND ANNEALING TEMPERATURE OF PRIMERS USED FOR RT-PCR}

\begin{tabular}{|c|c|c|c|c|}
\hline Gene & $\begin{array}{l}\text { Gen Bank } \\
\text { accession no. }\end{array}$ & Primer sequence (5'-3') & $\begin{array}{l}\text { Product } \\
\text { size (bp) }\end{array}$ & $\begin{array}{l}\text { Annealing } \\
\text { temp. }\left({ }^{\circ} \mathrm{C}\right)\end{array}$ \\
\hline Histone $\mathrm{H} 2 \mathrm{~A}$ & XM_002686056.3 & $\begin{array}{l}\text { F-CCAATATCCAGGCCGTGTTG } \\
\text { R-GGAGAGCTGGGTAGGACTTG }\end{array}$ & 97 & 60 \\
\hline POU5F1 (Oct 4) & NM_174580.2 & $\begin{array}{l}\text { F-TGGACAAGGAGAAGCTGGAG } \\
\text { R-ACATCGGCCTGGGTATATCC }\end{array}$ & 130 & 59 \\
\hline NANOG & NM_001025344.1 & $\begin{array}{l}\text { F-CATCTGCTGACACCCTCGAC } \\
\text { R-CACTCTGGGGCTTGTGGAAG }\end{array}$ & 101 & 62.5 \\
\hline SOX2 & NM_001105463.2 & $\begin{array}{l}\text { F-GACCTACATGAACGGCTCGC } \\
\text { R-AGCTGGCCTCGGACTTCA }\end{array}$ & 107 & 60 \\
\hline DNMT1 & NM_182651.2 & $\begin{array}{l}\text { F-GTGTGAGCCGAGTGAACTGG } \\
\text { R-GATGGCCCAAAGTGTCTCCG }\end{array}$ & 130 & 62.5 \\
\hline DNMT3A & NM_001206502.1 & $\begin{array}{l}\text { F-TCCGGGTGCTGTCTCTATTC } \\
\text { R-TGATGGAGTCCTCACACACC }\end{array}$ & 111 & 62.5 \\
\hline HDAC2 & NM_001075146.1 & $\begin{array}{l}\text { F-GAGGCGGCAAGAAGAAAGTC } \\
\text { R-GTTATGGGTCATGCGGATCC }\end{array}$ & 107 & 60 \\
\hline IGF2 & NM_174087.3 & $\begin{array}{l}\text { F-GTGACCTGTGGCCCTTGATC } \\
\text { R-CACCGACTTTCCTGCTGTGA }\end{array}$ & 96 & 62.5 \\
\hline IGF2R & NM_174352.2 & $\begin{array}{l}\text { F-CCGTCATCACCGAGTACCTG } \\
\text { R-CGAAGATGACCAGGGCGTAG }\end{array}$ & 126 & 59 \\
\hline$B A X$ & NM_173894.1 & $\begin{array}{l}\text { F-GTGCCCGAGTTGATCAGGAC } \\
\text { R-AAGTAGGAGAGGAGGCCGT }\end{array}$ & 110 & 59 \\
\hline$B C L 2$ & NM_001166486.1 & $\begin{array}{l}\text { F-CTTCGCCGAGATGTCCAGTC } \\
\text { R-TCACCCCGTCCCTGAAGA }\end{array}$ & 95 & 59 \\
\hline
\end{tabular}

\section{In vitro embryo production}

Bovine IVF derived embryos was produced as described previously (Shirazi et al., 2009). In brief, the in vitro matured oocytes were exposed to motile spermatozoa obtained by centrifugation of frozen-thawed semen on a discontinuous Percoll density gradient (40\% and $90 \%$ ) at $700 \mathrm{~g}$ for $20 \mathrm{~min}$. During IVF, oocytes were cultured in TALP medium supplemented with $6 \mathrm{mg} /$ $\mathrm{ml}$ BSA and incubated with motile spermatozoa at $1 \times 10^{6}$ spermatozoa $/ \mathrm{ml}$ concentration for $22-24 \mathrm{~h}$ at $39^{\circ} \mathrm{C}$ in $5 \% \mathrm{CO}$. After fertilization, presumptive zygotes were mechanically denuded and cultured in SOFaaBSA medium in $5 \% \mathrm{CO} 2,7 \% \mathrm{O} 2$, and $88 \% \mathrm{~N} 2$ for 9 days.

\section{Molecular evaluation}

\section{RNA extraction and $c D N A$ synthesis}

Total RNA was extracted from pools (six replicates) of 4 seven-day-old embryos at expanded blastocyst stage derived from NT and IVF, using RNX Plus reagent (RN7713C; Sinaclon Bioscience, Karaj, Iran). Briefly, samples were lysed in $300 \mu$ lof this reagent and mixed with $70 \mu \mathrm{l}$ chloroform. The resulting mixture was centrifuged (12000rpm, $4^{\circ} \mathrm{C}, 15 \mathrm{~min}$ ), yielding an upper aqueous phase containing total RNA. After addition of $120 \mu$ isopropanol and $4 \mu \mathrm{g} / \mu \mathrm{l}$ glycogen to supernatant, it was centrifuged $\left(12000 \mathrm{rpm}, 4^{\circ} \mathrm{C}, 15\right.$ $\mathrm{min}$ ) and the RNA pellet was washed with $75 \%$ ethanol. The RNA samples were re-suspended in 20ul DEPC-treated water and treated with RNase-free DNase (Sinaclon Bioscience, Karaj, Iran) to avoid amplification of contaminating genomic DNA. The amount and quality of RNA were determined by spectrophotometry (Amersham Pharmacia Ultrospec 1100 Pro). Only RNA of sufficient purity, having an absorbance ratio (A260/280) greater than 1.9, was considered for synthesis of cDNA. Total RNA was reverse transcribed into cDNA in a short time after extraction (less than $2 \mathrm{~h}$ ) using M-MLV reverse transcriptase (Sinaclon Bioscience, Karaj, Iran) as described by Hassanpour etal., (2015) (Hassanpour etal., 2015)(Hassanpour etal., 2015). The reversetranscription was done in a $20 \mu \mathrm{l}$ volume containing $10 \mu \mathrm{l}(14 \mu \mathrm{g})$ of extracted RNA and $1 \mu \mathrm{l}$ random hexamer. This mixture was heated to $70^{\circ} \mathrm{C}$ for $5 \mathrm{~min}$, and then $0.5 \mu$ l of RNase inhibitor, $2 \mu \mathrm{l}$ RT buffer $(50 \mathrm{mM}$ Tris- $\mathrm{HCl}, 75 \mathrm{mM} \mathrm{KCl}$, $3 \mathrm{mM} \mathrm{MgCl} 2), 2 \mu \mathrm{l}$ dNTP (10mM) and $1 \mu \mathrm{l} \mathrm{M-MLV} \mathrm{reverse} \mathrm{transcriptase} \mathrm{were}$ added. This mixture was incubated for $5 \mathrm{~min}$ at $25^{\circ} \mathrm{C}$, followed by $60 \mathrm{~min}$ at $42^{\circ} \mathrm{C}$. The mixture was heated to $70^{\circ} \mathrm{C}$ for $10 \mathrm{~min}$ to denature the RNA and then stored at $-20^{\circ} \mathrm{C}$. 


\section{Quantitative real-time PCR}

Real-time PCR was performed in two replicates for each sample (Rotor Gene Q 6000, Qiagen, USA). Primer sequences, the GenBank accession numbers, the size of amplified products, and annealing temperature of each primer are shown in Table 2. Half $\mu$ I DNase I treated cDNA (containing 0.35 $\mu \mathrm{g}$ ) was added to $10 \mu \mathrm{l}$ of SYBR Premix Ex Taq II Mix and $0.75 \mu \mathrm{M}$ of each specific primer in a total volume of $20 \mu \mathrm{l}$. The PCR program was comprised of 40 cycles of $94^{\circ} \mathrm{C}$ for $40 \mathrm{~s}, 59-62.5^{\circ} \mathrm{C}$ for $30 \mathrm{~s}$ (annealing temperature; table 1) and $72^{\circ} \mathrm{C}$ for $30 \mathrm{~s}$.

Considering the selection of an appropriate housekeeping gene as a reference gene for normalization, there are several studies demonstrating that Histone $\mathrm{H} 2$ a gene is highly reliable for analysis of relative gene expression in bovine embryos at blastocyst stage [Gutierrez-Adan et al., 2004; Rizos et al., 2002] and also for comparing the gene expression between bovine cloned and IVF embryos [Ross, et al., 2010]. It is of note that the level of H2A mRNA is itself an indicator of the proportion of DNA-replicating cells in the analysed embryos. Melt curve analysis was conducted to confirm the specificity of each product. The no-template control and no-reverse transcriptase control were considered to check contamination of the PCR reagents. Data were analyzed using LinReg PCR software version 2012.0 (USA), to give the threshold cycle number (Ct). Mean efficiency values (E) for each gene were also determined from the amplification profiles of individual samples using the same software (Ruijter et al., 2009). The following formula was applied to determine the relative gene expression in cloned embryos compared to the control group (IVF embryos)(Dorak, 2007, Pfaffl, 2001).

$$
\text { Ratio }=\frac{E_{H 2 A}\left(C_{t} \text { cloned embryos }\right) / E_{\text {target }}\left(C_{t} \text { cloned embryos }\right)}{E_{H 2 A}\left(C_{t} I V F \text { embryos }\right) / E_{\text {target }}\left(C_{t} I V F \text { embryos }\right)}
$$

\section{Statistical analysis}

The differences in relative abundance of gene expression and the percentages of embryonic development between groups were analyzed using one-way analysis of variance (ANOVA) after ArcSin transformation with SPSS software version 20.0.0 (IBM Corp.; USA). Data were expressed as mean \pm SEM. Differences were considered significant at $p<0.05$.

\section{Acknowledgments}

The authors thank the Research Institute of Animal Embryo Technology for technical and financial supports, Shahrekord University.

\section{References}

BERG, D.K., LI, C., ASHER, G., WELLS, D.N. and OBACK, B. (2007). Red deer cloned from antler stem cells and their differentiated progeny. Biol Reprod 77: 384-394.

BERMEJO-ALVAREZ, P., PERICUESTA, E., MIRANDA, A., DE FRUTOS, C., PEREZCEREZALES, S., LUCIO, A., RIZOS, D. and GUTIERREZ-ADAN, A. (2011). New challenges in the analysis of gene transcription in bovine blastocysts. Reprod Domest Anim 46 Suppl 3: 2-10.

BERTOLINI, M., BEAM, S.W., SHIM, H., BERTOLINI, L.R., MOYER, A.L., FAMULA, T.R. and ANDERSON, G.B. (2002). Growth, development, and gene expression by in vivo- and in vitro-produced day 7 and 16 bovine embryos. Mol Reprod Dev 63: 318-328.

BORTVIN, A., EGGAN, K., SKALETSKY, H., AKUTSU, H., BERRY, D.L., YANAGIMACHI, R., PAGE, D.C. and JAENISCH, R. (2003). Incomplete reactivation of Oct4-related genes in mouse embryos cloned from somatic nuclei. Development 130: 1673-1680.

BOSCH, P., PRATT, S.L. and STICE, S.L. (2006). Isolation, characterization, gene modification, and nuclear reprogramming of porcine mesenchymal stem cells. Biol Reprod 74: 46-57.

BOURC'HIS, D., LE BOURHIS, D., PATIN, D., NIVELEAU, A., COMIZZOLI, P., RENARD, J.P. and VIEGAS-PEQUIGNOT, E. (2001). Delayed and incomplete reprogramming of chromosome methylation patterns in bovine cloned embryos. Curr Biol 11: 1542-1546.

COLLEONI, S., DONOFRIO, G., LAGUTINA, I., DUCHI, R., GALLI, C. and LAZZARI, G. (2005). Establishment, differentiation, electroporation, viral transduction, and nuclear transfer of bovine and porcine mesenchymal stem cells. Cloning Stem Cells 7: 154-166.

DEAN, W., BOWDEN, L., AITCHISON, A., KLOSE, J., MOORE, T., MENESES, J.J. REIK, W. and FEIL, R. (1998). Altered imprinted gene methylation and expression in completely ES cell-derived mouse fetuses: association with aberrant phenotypes. Development 125: 2273-2282.

DEAN, W., SANTOS, F., STOJKOVIC, M., ZAKHARTCHENKO, V., WALTER, J. WOLF, E. and REIK, W. (2001). Conservation of methylation reprogramming in mammalian development: aberrant reprogramming in cloned embryos. Proc Natl Acad Sci USA 98: 13734-13738.

DOHERTY, A.S., MANN, M.R., TREMBLAY, K.D., BARTOLOMEI, M.S. and SCHULTZ, R.M. (2000). Differential effects of culture on imprinted $\mathrm{H} 19$ expression in the preimplantation mouse embryo. Biol Reprod 62: 1526-1535.

DORAK, M.T. (2007). Real-time PCR. Taylor \& Francis.

ENRIGHT, B.P., SUNG, L.Y., CHANG, C.C., YANG, X. and TIAN, X.C. (2005). Methylation and acetylation characteristics of cloned bovine embryos from donor cells treated with 5-aza-2'-deoxycytidine. Biol Reprod 72: 944-948.

FAAST, R., HARRISON, S.J., BEEBE, L.F., MCILFATRICK, S.M., ASHMAN, R.J. and NOTTLE, M.B. (2006). Use of adult mesenchymal stem cells isolated from bone marrow and blood for somatic cell nuclear transfer in pigs. Cloning Stem Cells 8: 166-173.

FEIL, R. (2001). Early-embryonic culture and manipulation could affect genomic imprinting. Trends Mol Med 7: 245-246.

GOLDING, M.C. and WESTHUSIN, M.E. (2003). Analysis of DNA (cytosine 5) methyltransferase mRNA sequence and expression in bovine preimplantation embryos, fetal and adult tissues. Gene Expr Patterns 3: 551-558.

GUTIERREZ-ADAN, A., RIZOS, D., FAIR, T., MOREIRA, P.N., PINTADO, B., DE LA FUENTE, J., BOLAND, M.P. and LONERGAN, P. (2004). Effect of speed of development on mRNA expression pattern in early bovine embryos cultured in vivo or in vitro. Mol Reprod Dev 68: 441-448.

HAN, D.W., SONG, S.J., UHUM, S.J., DO, J.T., KIM, N.H., CHUNG, K.S. and LEE, H.T. (2003). Expression of IGF2 and IGF receptor mRNA in bovine nuclear transferred embryos. Zygote 11: 245-252.

HASSANPOUR, H., NIKOUKAR, Z., NASIRI, L. and BAHADORAN, S. (2015) Differential gene expression of three nitric oxide synthases is consistent with increased nitric oxide in the hindbrain of broilers with cold-induced pulmonary hypertension. Br Poult Sci 56: 436-442.

HOSSEINI, S.M., HAJIAN, M., FOROUZANFAR, M., OSTADHOSSEINI, S., MOULAVI, F., GHANAEI, H.R., GOURBAI, H., SHAHVERDI, A.H., VOSOUGH, A.D. and NASR-ESFAHANI, M.H. (2015). Chemically assisted somatic cell nuclear transfer without micromanipulator in the goat: effects of demecolcine, cytochalasin-B, and MG-132 on the efficiency of a manual method of oocyte enucleation using a pulled Pasteur pipette. Anim Reprod Sci 158: 11-18.

HOSSEINI, S.M., HAJIAN, M., MOULAVI, F., ASGARI, V., FOROUZANFAR, M. and NASR-ESFAHANI, M.H. (2013a). Cloned sheep blastocysts derived from oocytes enucleated manually using a pulled pasteur pipette. Cell Reprogram 15: 15-23.

HOSSEINI, S.M., MOULAVI, F., ASGARI, V., SHIRAZI, A., ABAZARI-KIA, A.H. GHANAEI, H.R. and NASR-ESFAHANI, M.H. (2013b). Simple, fast, and efficient method of manual oocyte enucleation using a pulled Pasteur pipette. In vitro Cell Dev Biol Anim 49: 569-575.

JAENISCH, R., HOCHEDLINGER, K., BLELLOCH, R., YAMADA, Y., BALDWIN, K and EGGAN, K. (2004). Nuclear cloning, epigenetic reprogramming, and cellular differentiation. Cold Spring Harb Symp Quant Biol 69: 19-27.

JIN, H.F., KUMAR, B.M., KIM, J.G., SONG, H.J., JEONG, Y.J., CHO, S.K., BALASUBRAMANIAN, S., CHOE, S.Y. and RHO, G.J. (2007). Enhanced development of porcine embryos cloned from bone marrow mesenchymal stem cells. Int J Dev Biol 51: 85-90.

KATO, Y., IMABAYASHI, H., MORI, T., TANI, T., TANIGUCHI, M., HIGASHI, M., MATSUMOTO, M., UMEZAWA, A. and TSUNODA, Y. (2004). Nuclear transfer of adult bone marrow mesenchymal stem cells: developmental totipotency of tissuespecific stem cells from an adult mammal. Biol Reprod 70: 415-418.

KEEFER, C.L. (2015). Artificial cloning of domestic animals. Proc Natl Acad Sci USA 112: 8874-8878.

KIM, G.A., OH, H.J., LEE, T.H., LEE, J.H., OH, S.H., LEE, J.H., KIM, J.W., KIM, S.W and LEE, B.C. (2014). Effect of culture medium type on canine adipose-derived mesenchymal stem cells and developmental competence of interspecies cloned 
embryos. Theriogenology 81: 243-249.

KUMAR, B.M., JIN, H.F., KIM, J.G., OCK, S.A., HONG, Y., BALASUBRAMANIAN, S., CHOE, S.Y. and RHO, G.J. (2007). Differential gene expression patterns in porcine nuclear transfer embryos reconstructed with fetal fibroblasts and mesenchymal stem cells. Dev Dyn 236: 435-446.

KUMAR, B.M., MAENG, G., JEON, R., LEE, Y., LEE, W., JEON, B., OCK, S. and RHO, G. (2012). Developmental expression of lineage specific genes in porcine embryos of different origins. J Assist Reprod Genet 29: 723-733.

LATHAM, K.E., DOHERTY, A.S., SCOTT, C.D. and SCHULTZ, R.M. (1994). Igf2r and Igf2 gene expression in androgenetic, gynogenetic, and parthenogenetic preimplantation mouse embryos: absence of regulation by genomic imprinting. Genes Dev 8: 290-299.

LEE, J.H., LEE, W.J., JEON, R.H., LEE, Y.M., JANG, S.J., LEE, S.L., JEON, B.G., OCK, S.A., KING, W.A. and RHO, G.J. (2014). Development and gene expression of porcine cloned embryos derived from bone marrow stem cells with overexpressing Oct4 and Sox2. Cell Reprogram 16: 428-438.

LEE, K., FODOR, W.L. and MACHATY, Z. (2006). 55 INFLUENCE OF DONOR CELL TYPE ON THE DEVELOPMENT OF PORCINE NUCLEAR TRANSFER EMBRYOS. Reprod. Fert. Dev. 18: 136-136.

LI, Z., HE, X., CHEN, L., SHI, J., ZHOU, R., XU, W., LIU, D. and WU, Z. (2013). Bone marrow mesenchymal stem cells are an attractive donor cell type for production of cloned pigs as well as genetically modified cloned pigs by somatic cell nuclear transfer. Cell Reprogram 15: 459-470.

MCELROY, S.L., KIM, J.H., KIM, S., JEONG, Y.W., LEE, E.G., PARK, S.M., HOSSEIN, M.S., KOO, O.J., ABUL HASHEM, M.D., JANG, G. et al., (2008). Effects of culture conditions and nuclear transfer protocols on blastocyst formation and mRNA expression in pre-implantation porcine embryos. Theriogenology 69: 416-425.

METCALFE, A.D., HUNTER, H.R., BLOOR, D.J., LIEBERMAN, B.A., PICTON, H.M., LEESE, H.J., KIMBER, S.J. and BRISON, D.R. (2004). Expression of 11 members of the BCL-2 family of apoptosis regulatory molecules during human preimplantation embryo development and fragmentation. Mol Reprod Dev 68: 35-50.

MITSUI, K., TOKUZAWA, Y., ITOH, H., SEGAWA, K., MURAKAMI, M., TAKAHASHI, K., MARUYAMA, M., MAEDA, M. and YAMANAKA, S. (2003). The homeoprotein Nanog is required for maintenance of pluripotency in mouse epiblast and ES cells. Cell 113: 631-642.

NIEMANN, H., TIAN, X.C., KING, W.A. and LEE, R.S. (2008). Epigenetic reprogramming in embryonic and foetal development upon somatic cell nuclear transfer cloning. Reproduction 135: 151-163.

NIEMANN, H., WRENZYCKI, C., LUCAS-HAHN, A., BRAMBRINK, T., KUES, W.A. and CARNWATH, J.W. (2002). Gene expression patterns in bovine in vitro-produced and nuclear transfer-derived embryos and their implications for early development. Cloning Stem Cells 4: 29-38.

PFAFFL, M.W. (2001). A new mathematical model for relative quantification in realtime RT-PCR. Nucleic Acids Res 29: e45.

RIDEOUT, W.M., 3RD, WAKAYAMA, T., WUTZ, A., EGGAN, K., JACKSON-GRUSBY, L., DAUSMAN, J., YANAGIMACHI, R. and JAENISCH, R. (2000). Generation of mice from wild-type and targeted ES cells by nuclear cloning. Nat Genet 24: 109-110.

RIZOS, D., LONERGAN, P., BOLAND, M.P., ARROYO-GARCIA, R., PINTADO, B., DE LA FUENTE, J. and GUTIERREZ-ADAN, A. (2002). Analysis of differential messenger RNA expression between bovine blastocysts produced in different culture systems: implications for blastocyst quality. Biol Reprod 66: 589-595.

RODRIGUEZ-ALVAREZ, L., MANRIQUEZ, J., VELASQUEZ, A. and CASTRO, F.O. (2013). Constitutive expression of the embryonic stem cell marker OCT4 in bovine somatic donor cells influences blastocysts rate and quality after nucleus transfer. In vitro Cell Dev Biol Anim 49: 657-667.

RODRIGUEZ-OSORIO, N., URREGO, R., CIBELLI, J.B., EILERTSEN, K. and MEMILI, E. (2012). Reprogramming mammalian somatic cells. Theriogenology 78: $1869-1886$
RODRIGUEZ-OSORIO, N., WANG, Z., KASINATHAN, P., PAGE, G.P., ROBL, J.M and MEMILI, E. (2009). Transcriptional reprogramming of gene expression in bovine somatic cell chromatin transfer embryos. BMC Genomics 10: 190-190.

ROSS, P.J., WANG, K., KOCABAS, A. and CIBELLI, J.B. (2010). Housekeeping gene transcript abundance in bovine fertilized and cloned embryos. Cell Reprogram 12: 709-717.

RUIJTER, J.M., RAMAKERS, C., HOOGAARS, W.M.H., KARLEN, Y., BAKKER, O., VAN DEN HOFF, M.J.B. and MOORMAN, A.F.M. (2009). Amplification efficiency: linking baseline and bias in the analysis of quantitative PCR data. Nucleic Acids Res. 37: e45-e45.

SAMIEC, M., OPIELA, J., LIPIŃSKI, D. and ROMANEK, J. (2015). Trichostatin AMediated Epigenetic Transformation of Adult Bone Marrow-Derived Mesenchymal Stem Cells Biases the In vitro Developmental Capability, Quality, and Pluripotency Extent of Porcine Cloned Embryos. BioMed Res. Int. 2015: 814686.

SAMIEC, M. and SKRZYSZOWSKA, M. (2005). Molecular conditions of the cell nucleus remodelling/reprogramming process and nucleartransferred embryo development in the intraooplasmic karyoplast injection technique: a review. Czech J Anim Sci 5: 185-195.

SANTOS, F., ZAKHARTCHENKO, V., STOJKOVIC, M., PETERS, A., JENUWEIN, T., WOLF, E., REIK, W. and DEAN, W. (2003). Epigenetic marking correlates with developmental potential in cloned bovine preimplantation embryos. Curr Biol 13: 1116-1121.

SHIRAZI, A., NAZARI, H., AHMADI, E., HEIDARI, B. and SHAMS-ESFANDABADI, N. (2009). Effect of culture system on survival rate of vitrified bovine embryos produced in vitro. Cryobiology 59: 285-90.

SUNG, L.Y., GAO, S., SHEN, H., YU, H., SONG, Y., SMITH, S.L., CHANG, C.C., INOUE, K., KUO, L., LIAN, J. et al., (2006). Differentiated cells are more efficient than adult stem cells for cloning by somatic cell nuclear transfer. Nat Genet 38 1323-1328.

TODA, A., OKABE, M., YOSHIDA, T. and NIKAIDO, T. (2007). The potential of amniotic membrane/amnion-derived cells for regeneration of various tissues. $J$ Pharmacol Sci 105: 215-228.

VAJTA, G., PEURA, T.T., HOLM, P., PALDI, A., GREVE, T., TROUNSON, A.O. and CALLESEN, H. (2000). New method for culture of zona-included or zona-free embryos: the Well of the Well (WOW) system. Mol Reprod Dev 55: 256-64.

WOLFFE, A.P. and PRUSS, D. (1996). Targeting chromatin disruption: Transcription regulators that acetylate histones. Cell 84: 817-819.

WRENZYCKI, C., HERRMANN, D., KESKINTEPE, L., MARTINS, A., JR., SIRISATHIEN, S., BRACKETT, B. and NIEMANN, H. (2001a). Effects of culture system and protein supplementation on mRNA expression in pre-implantation bovine embryos. Hum Reprod 16: 893-901.

WRENZYCKI, C., WELLS, D., HERRMANN, D., MILLER, A., OLIVER, J., TERVIT, R. and NIEMANN, H. (2001b). Nuclear transfer protocol affects messenger RNA expression patterns in cloned bovine blastocysts. Biol Reprod 65: 309-317.

ZHANG, L., LUO, Y.B., BOU, G., KONG, Q.R., HUAN, Y.J., ZHU, J., WANG, J.Y., LI, H., WANG, F., SHI, Y.Q. et al., (2011). Overexpression Nanog activates pluripotent genes in porcine fetal fibroblasts and nuclear transfer embryos. Anat Rec (Hoboken) 294: 1809-1817.

ZHENG, Y.M., ZHAO, H.Y., ZHAO, X.E., QUAN, F.S., HUA, S., HE, X.Y., LIU, J., HE X.N. and LIN, H. (2009). Development of cloned embryos from porcine neural stem cells and amniotic fluid-derived stem cells transfected with enhanced green fluorescence protein gene. Reproduction 137: 793-801.

ZHU, H., CRAIG, J.A., DYCE, P.W., SUNNEN, N. and LI, J. (2004). Embryos derived from porcine skin-derived stem cells exhibit enhanced preimplantation development. Biol Reprod 71: 1890-1897. 


\section{Further Related Reading, published previously in the Int. J. Dev. Biol.}

Enhanced development of porcine embryos cloned from bone marrow mesenchymal stem cells Jin, H.F., Kumar, B.M., Kim, J.G., Song, H.J., Jeong, Y.J., Cho, S.K., Balasubramanian, S., Choe, S.Y. and Rho, G.J. Int. J. Dev. Biol. (2007) 51: 85-90.

http://www.ijdb.ehu.es/web/paper/062165hj

Role of the donor nuclei in cloning efficiency: can the ooplasm reprogram any nucleus? Yoko Kato and Yukio Tsunoda

Int. J. Dev. Biol. (2010) 54: 1623-1629

http://dx.doi.org/10.1387/ijdb.103203yk

\section{Nuclear reprogramming in zygotes}

Chanchao Lorthongpanich, Davor Solter and Chin Yan Lim

Int. J. Dev. Biol. (2010) 54: 1631-1640

http://dx.doi.org/10.1387/ijdb.103201cl

Faithful reprogramming to pluripotency in mammals - what does nuclear transfer teach us?

Julien Maruotti, Alice Jouneau and Jean-Paul Renard

Int. J. Dev. Biol. (2010) 54: 1609-1621

http://dx.doi.org/10.1387/ijdb.103195jm

Epigenetic asymmetry in the zygote and mammalian development

Robert Feil

Int. J. Dev. Biol. (2009) 53: 191-201

http://dx.doi.org/10.1387/ijdb.082654rf

5 yr ISI Impact Factor $(2013)=2.879$

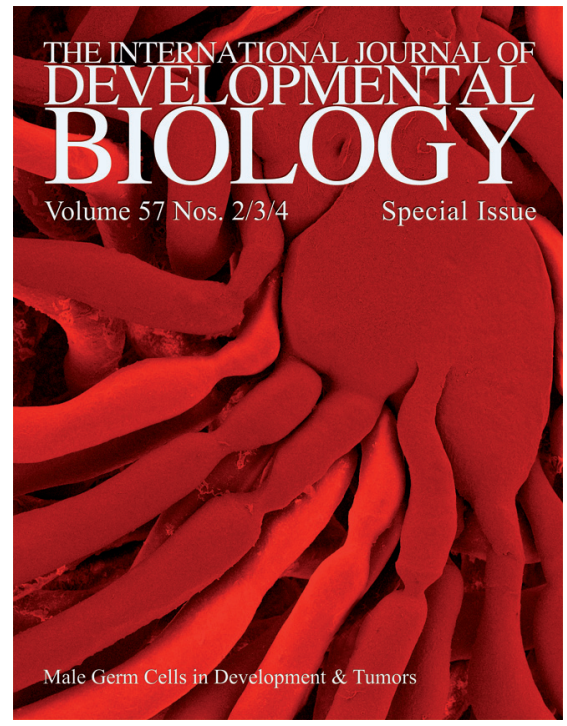

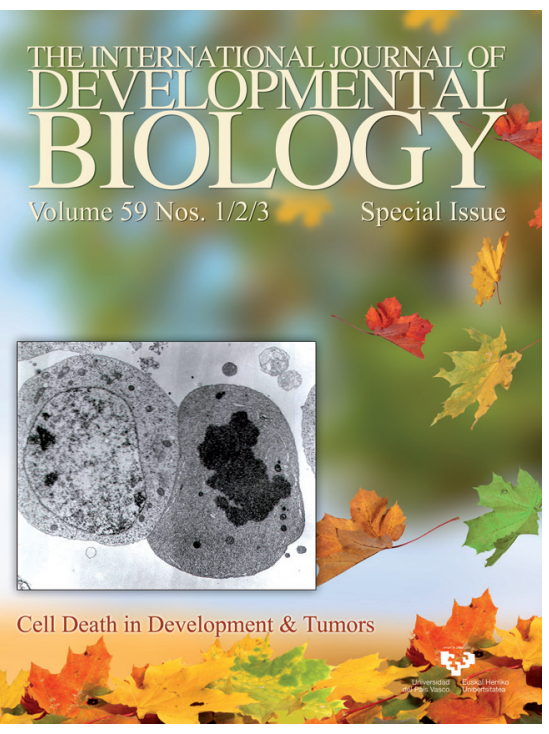
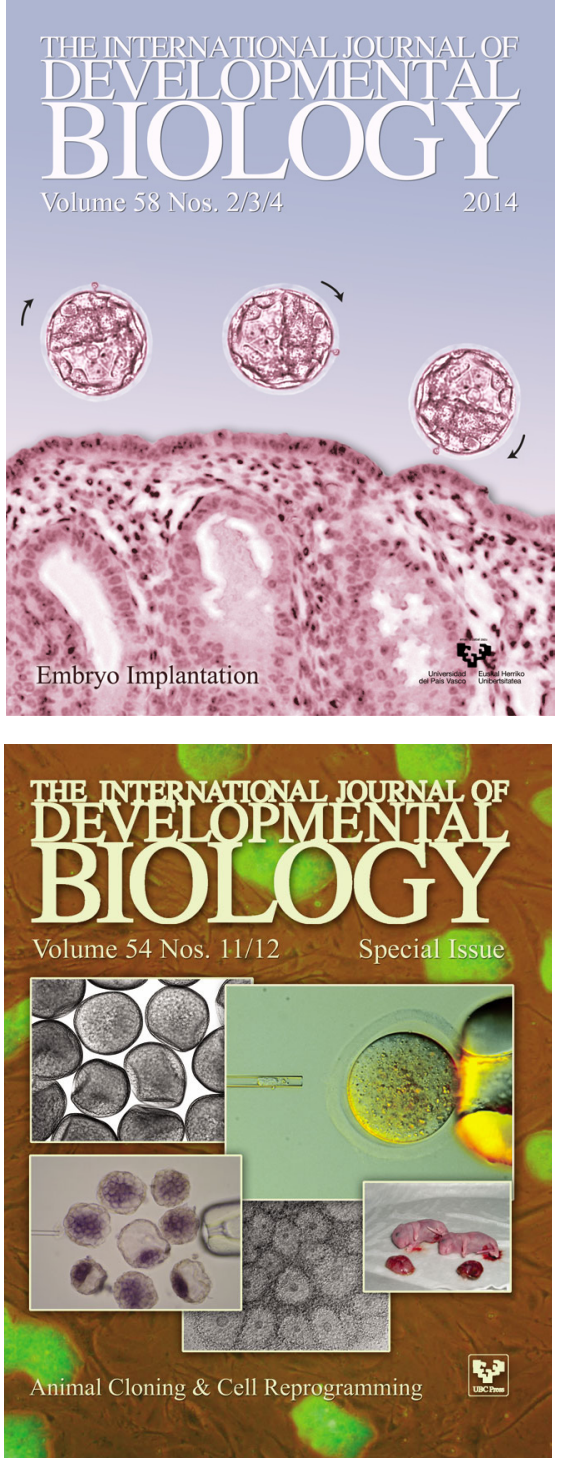